\title{
LetTeR tO THE EDITOR/LIST DO REDAKCJI
}

\section{Pseudo-Kaposi sarcoma}

\section{Pseudomięsak Kaposiego}

\author{
Ewelina A. Rebizak, Jolanta Węgłowska, Katarzyna Łuczak \\ Voivodeship Research and Development Centre, Wroclaw, Poland \\ Wojewódzki Ośrodek Badawczo-Rozwojowy we Wrocławiu, Polska
}

A 39-year-old woman was admitted to the clinic in September 2017 due to exanthema found on lower legs. The patient could not specify when the first skin lesions appeared. Concurrent diseases include schizophrenia.

Physical examination confirmed bilateral extensive lesions on lower legs with blue and scarlet papulae merging into bigger plaques; they were initially covered with papillary buildup (fig. 1). Shallow ulceration on the extensor surface of a lower leg. Laboratory test results did not show any deviations from reference values. Serum test for HIV antibodies and p24 antigen was negative. Doppler ultrasound of lower limb veins revealed venous insufficiency and signs of postphlebitic syndrome. A sample of nodular exanthema was taken for histopathological examination. The biopsy showed a regular pattern of blood vessel proliferation, fibroblasts, extravasated erythrocytes, and hemosiderin deposits in dermis. Neither atypical cells nor endothelial vascular cracks were identified. Immunohistochemical analysis using monoclonal antibodies against CD34 antigen confirmed a positive reaction within endothelial cells of blood vessels, and a negative one within pericytes, what in turn confirmed the diagnosis of pseudo-Kaposi sarcoma (acroangiodermatitis). Implemented treatment involved compression therapy and topical corticosteroids, and $0.25 \%$ of silver nitrate solution for ulcers. After a week, a remission of erosive lesions was achieved; skin lesions were still present, although less intense (figs. $2 \mathrm{~A}, \mathrm{~B}$ ).

Acroangiodermatitis (AAD), also referred to as pseudo-Kaposi sarcoma, is a vascular-proliferative disease characterized by reactive proliferation of small blood vessels in response to congenital or acquired vascular lesions. The changes initially appear as limited, slow-growing, red, purplish or dark macules, papules or plaques, which over time become
Kobieta 39-letnia została przyjęta do kliniki we wrześniu 2017 r. z powodu wykwitów skórnych zlokalizowanych na podudziach. Pacjentka nie potrafiła określić, kiedy pojawiły się pierwsze zmiany skórne. Kobieta chorowała na schizofrenię.

W badaniu przedmiotowym stwierdzono obustronnie na podudziach rozległe zmiany w postaci sinopurpurowych grudek zlewających się w większe blaszki, początkowo pokryte brodawkowatymi nawarstwieniami (ryc. 1). Na wyprostnej powierzchni podudzia prawego obserwowano płytkie owrzodzenie. $W$ badaniach laboratoryjnych nie wykazano odchyleń od wartości referencyjnych. Wynik badania surowicy w kierunku przeciwciał anty-HIV oraz antygenu p24 był ujemny. W badaniu ultrasonograficznym metodą Dopplera żył kończyn dolnych stwierdzono niewydolność żylną oraz cechy zespołu pozakrzepowego. Pobrano wycinek do badania histopatologicznego z wykwitów guzkowych. Biopsja wykazała regularny wzór proliferacji naczyń krwionośnych, fibroblastów, wynaczynionych erytrocytów i odkładania hemosyderyny w skórze właściwej. Nie zidentyfikowano komórek atypowych ani szczelin naczyniowych śródbłonka. W badaniu immunohistochemicznym z zastosowaniem przeciwciała monoklonalnego przeciwko antygenowi CD34 stwierdzono dodatnią reakcję w obrębie komórek śródbłonka naczyń krwionośnych oraz ujemną reakcję w obrębie perycytów, co potwierdziło rozpoznanie pseudosarcoma Kaposi (acroangiodermatitis). Wdrożono leczenie $\mathrm{w}$ formie kompresjoterapii oraz miejscowo glikokortykosteroidów, a na owrzodzenia zastosowano roztwór azotanu srebra o stężeniu $0,25 \%$. Po tygodniu osiągnięto remisję zmian nadżerkowych, zmiany skórne były nadal obecne, choć mniej nasilone (ryc. 2 A, B).

Acroangiodermatitis (AAD), opisywane również jako pseudomięsak Kaposiego, jest chorobą naczyniowo-proliferacyjną charakteryzującą się reaktywną proliferacją małych naczyń krwionośnych w odpowiedzi 
papillary, and can also form ulcers. There are four clinical variants of AAD, the most common type: 1) Mali is associated with venous hypertension; 2 ) the Stewart-Bluefarb type is associated with congenital arteriovenous malformation (AVM);3) there is also a less frequent one in patients with chronic renal failure with acquired arteriovenous fistula; and 4) a form occurring in pregnant women.

Mali et al. for the first time introduced the term acroangiodermatitis in 1965. Eighteen patients with purple and red speckles and papulae mostly on dorsal surface of feet with chronic vascular insufficiency (CVI) were described. In 1967 Stewart, Bluefarb and Adams independently described morphologically similar lesions found on legs of patients with arteriovenous malformations (AVM) [1]. Pseudo-Kaposi sarcoma is reactive angiodysplasia of cutaneous blood vessels observed together with venous insufficiency or some vascular anomalies [2]. It is a mild condition, whose clinical presentation includes purple speckles, sclerotic plaques or nodules that are usually found on the extensor surfaces of lower limbs. Although it has a mild character, it should be differentiated from neoplastic diseases, such as Kaposi sarcoma, especially in the present HIV-age; thus, histopathological exam is a necessary condition for its diagnosis and differentiation [2, 3]. Histologically speaking, similarity to Kaposi sarcoma lies in its neoplastic proliferation of small vessels with leucocytes and hemosiderin-laden macrophages. Histologically, differential diagnostics includes also vascular forms of fibrous histiocytoma, or other haemangioma [4]. Immunohistochemical staining with CD34 antigen helps differentiate acroangiodermatitis from Kaposi sarcoma, as in the former there is no perivascular CD34 as compared with the latter (CD34 staining of endothelial cells, and perivascular spindle cells) $[5,6]$.

Disease's aetiology has not been fully discovered yet. It is assumed that chronic venostasis with calf na wrodzone lub nabyte zmiany naczyniowe. Zmiany początkowo pojawiają się jako ograniczone, wolno rozwijające się, czerwone, fioletowawe lub ciemne plamki, grudki lub płytki, które z czasem stają się brodawkowate; mogą też tworzyć się owrzodzenia. Istnieją cztery warianty kliniczne AAD: 1) typu Maliego, związane z nadciśnieniem żylnym, 2) typu Stewarta-Bluefarba, związane z wrodzoną malformacją tętniczo-żylną (arteriovenous malformations - AVM) oraz rzadziej występujące 3) u pacjentów z przewlekłą niewydolnością nerek z nabytą przetoką tętniczo-żylną i 4) u kobiet w ciąży.

Termin acroangiodermatitis został po raz pierwszy wprowadzony przez Maliego i wsp. w 1965 r. Opisali oni 18 pacjentów z przewlekłą niewydolnością żył (chronic venous insufficiency - CVI) z fioletowo-czerwonymi plamkami i grudkami, przede wszystkim na zewnętrznej powierzchni stóp. W 1967 r. morfologicznie podobne zmiany na kończynach dolnych pacjentów z AVM opisali niezależnie Stewart oraz Bluefarb i Adams [1]. Pseudomięsak Kaposiego jest reaktywną angiodysplazją skórnych naczyń krwionośnych, często obserwowaną w związku z niewydolnością żylną lub z pewnymi anomaliami naczyniowymi [2]. Jest to łagodny stan, który klinicznie ma postać fioletowych plamek, stwardniałych blaszek lub guzków, zwykle występujących obustronnie na wyprostnych powierzchniach kończyn dolnych. Chociaż ma łagodny charakter, musi być odróżniony od chorób nowotworowych, takich jak mięsak Kaposiego, zwłaszcza w erze HIV, dlatego badanie histopatologiczne jest koniecznym warunkiem rozpoznania i różnicowania $[2,3]$. Podobieństwo do mięsaka Kaposiego histologicznie wynika z nowotworowej proliferacji małych naczyń z wtrąconymi limfocytami i makrofagami obciążonymi hemosyderyną. Histologicznie diagnostyka różnicowa obejmuje także formy naczyniowe włóknistego histiocytoma i innych naczyniaków krwionośnych [4]. Barwienie immunohistochemiczne
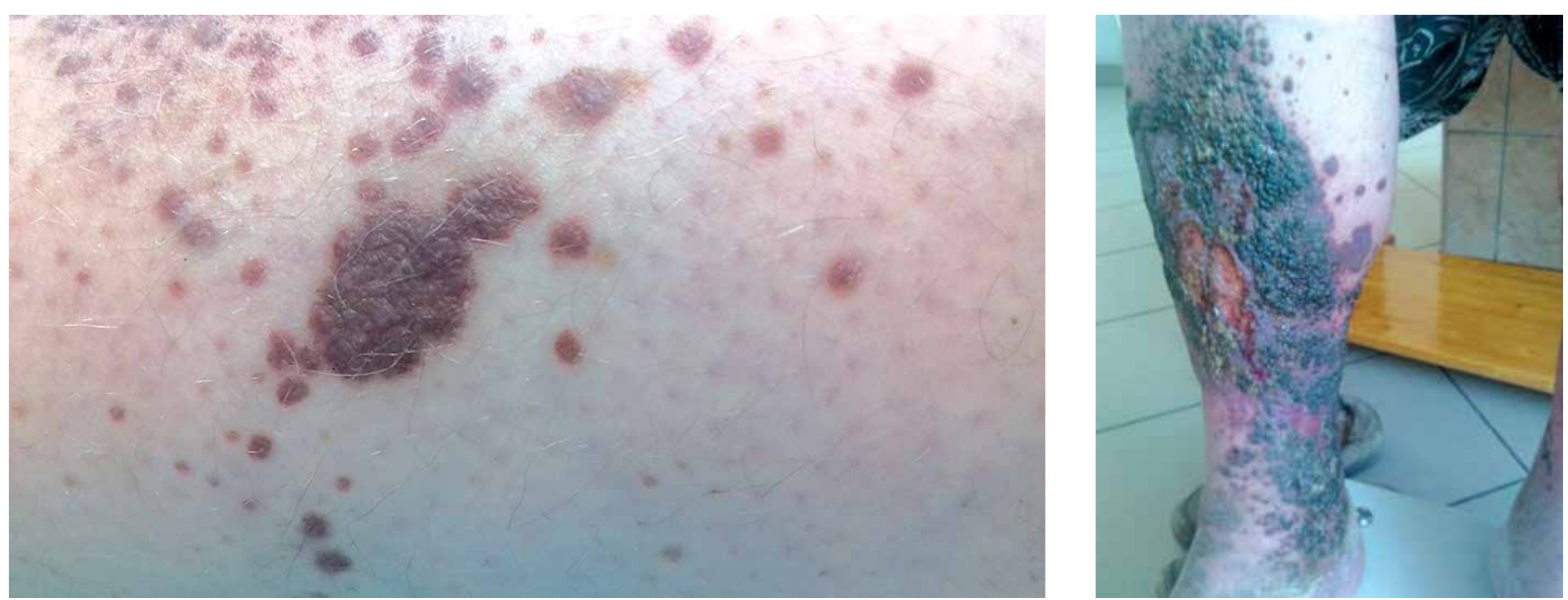

Figure I. Skin lesions before the treatment; papillary masses covering blue and purple plaques

Rycina I. Zmiany skórne przed leczeniem, brodawkowate masy pokrywające sinopurpurowe blaszki 
muscle pump insufficiency increases capillary pressure and leads to chronic hypoxia, persistent oede$\mathrm{ma}$, which induces neovascularization and fibroblast proliferation $[7,8]$. Then, vascular endothelial growth factors are released, which in hypoxic conditions play an important role in angiogenesis. Products released during mast cell degranulation, such as heparin, histamine, and TNF- $\alpha$, are responsible for neoagniogenesis by stimulating stem cell factor $[3,7,8]$.

Treatment of this condition is seldom discussed in papers and depends on the underlying circulatory disorders. In case of chronic venous insufficiency, compression bandages may alleviate the symptoms $[3,9]$. Topical application of topical glucocorticosteroid preparations is often helpful [10]. Other therapeutically successful treatment regimens were also described: oral erythromycin in the dose of $500 \mathrm{mg}$ four times a day, or dapsone in the dose of $50 \mathrm{mg}$ twice a day for 3 months combined with a compression therapy [3]. In case of vascular pathologies, such as arteriovenous malformations the following may be applied: surgical treatment eliminating fistula and embolization in case of small fistulas. Laser ablation with a pulsed dyed laser may remove some individual lesions [8]. In the above-described case, topical glucocorticosteroids and compression therapy provided beneficial results.

Acroangiodermatitis is a rare disease, and may imitate a number of various clinical conditions, such as Kaposi sarcoma, Schamberg's disease, vasculitis, haemangioma, lymphangioma, and lymphosarcoma. Therefore, wrong diagnoses are often given. Histopathological similarity to Kaposi sarcoma and other vascular neoplasms may also be misleading for specialists with little experience. An incorrect diagnosis may lead to wrong treatment, such as a surgery and its possible complications. przy użyciu antygenu CD34 pomaga odróżnić AAD od mięsaka Kaposiego, ponieważ w tym pierwszym przypadku obserwuje się brak okołonaczyniowego CD34, w przeciwieństwie do tego drugiego (barwienie CD34 na komórkach śródbłonka, a także w okołonaczyniowych komórkach wrzecionowatych) [5, 6].

Etiologia schorzenia nie jest dokładnie poznana. Postuluje się, że przewlekły zastój żylny z niewydolnością pompy mięśniowej łydek podwyższa ciśnienie kapilarne i prowadzi do chronicznego niedotlenienia tkanek, przewlekłego obrzęku, który indukuje neowaskularyzację i proliferację fibroblastów $[7,8]$. Dochodzi do miejscowego uwalniania czynników wzrostu śródbłonka naczyniowego, które w warunkach niedotlenienia odgrywają ważną rolę w angiogenezie. Produkty uwalniane podczas degranulacji komórek tucznych, takie jak heparyna, histamina i TNF- $\alpha$, odpowiadają za neoangiogenezę $z$ uwagi na stymulację czynnika komórek macierzystych [3, 7, 8].

Leczenie tego stanu jest rzadko omawiane w piśmiennictwie i zależy od charakteru czynników leżących u podstaw zaburzeń krążenia. W przypadkach przewlekłej niewydolności żylnej stosowanie bandaży uciskowych może złagodzić objawy [3, 9]. Często przydatne są preparaty glikokortykosteroidowe stosowane miejscowo [10]. Opisano także inne schematy terapii, w których uzyskano dobry efekt, takie jak erytromycyna stosowana doustnie $\mathrm{w}$ dawce $500 \mathrm{mg}$ 4 razy dziennie lub dapson w dawce $50 \mathrm{mg} 2$ razy dziennie przez 3 miesiące $\mathrm{w}$ połączeniu $\mathrm{z}$ terapią uciskową [3]. W przypadku patologii naczyniowych, takich jak malformacje tętniczo-żylne, można zastosować leczenie chirurgiczne, eliminując przetoki, a także embolizację w przypadku małych przetok. Niektóre pojedyncze zmiany można usunąć metodą ablacji pulsacyjnym laserem barwnikowym [8]. W przedstawionym przypadku korzystny efekt uzyskano, stosując miejscowo glikokortykosteroidy oraz kompresjoterapię.

Acroangiodermatitis jest rzadko występującym schorzeniem, może imitować liczne stany kliniczne, takie jak mięsak Kaposiego, plamica barwnikowa,
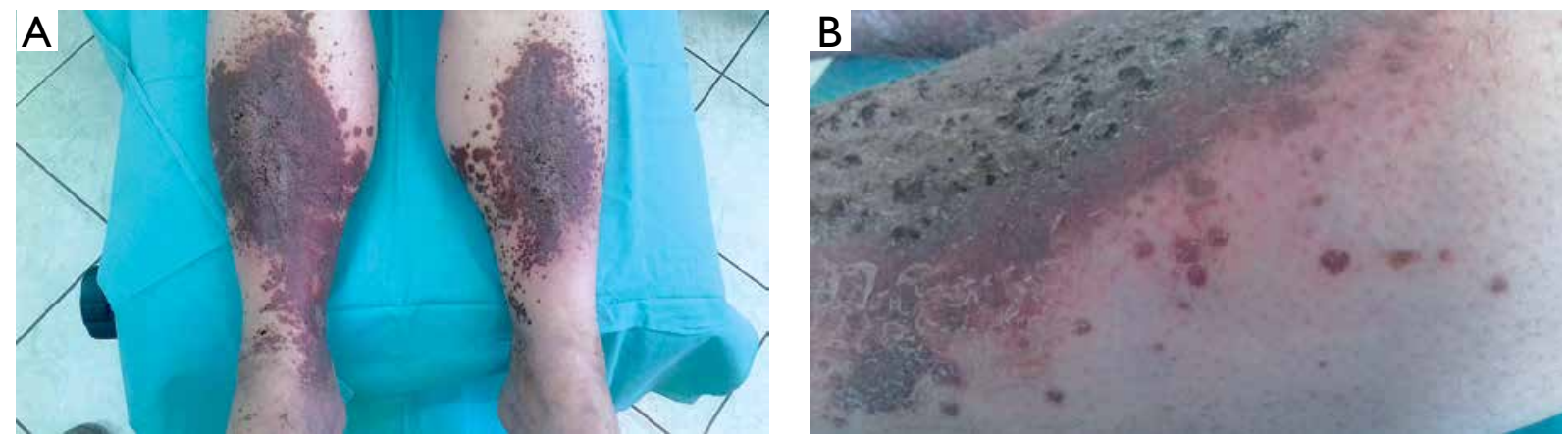

Figure 2 A, B. Skin lesions after the removal of buildup covering them; status post healing the ulcers

Rycina 2 A, B. Zmiany skórne po usunięciu pokrywających je nawarstwień, stan po wygojeniu owrzodzeń 


\section{CONFLICT OF INTEREST}

The authors declare no conflict of interest. zapalenie naczyń, naczyniak krwionośny, naczyniaki limfatyczne i mięsak limfatyczny. Z tego powodu często zdarzają się błędne diagnozy. Cechy histopatologiczne podobne do mięsaka Kaposiego i innych nowotworów naczyniowych mogą również mylić specjalistów z niewielkim doświadczeniem. Błędna diagnoza może prowadzić do niewłaściwego leczenia, np. do przeprowadzenia operacji, z konsekwencjami w postaci powikłań.

\section{KONFLIKT INTERESÓW}

Autorzy nie zgłaszają konfliktu interesów.

\section{References}

\section{Piśmiennictwo}

1. Jindal R., De D., Dogra S., Saikia U.N., Kanwar A.J.: Acroangiodermatitis of Mali in a patient with congenital myopathy. Dermatol Online J 2010, 16, 4.

2. Heller M., Karen J.K., Fangman W.: Acroangiododermatitis. Dermatol Online J 2007, 13, 2.

3. Mehta A.A., Pereira R.R., Nayak C.S., Dhurat R.S.: Acroangiodermatitis of mali: a rare vascular phenomenon. Indian J Dermatol Venereol Leprol 2010, 76, 553-556.

4. Hung N.A., Strack M., Van Rij A., North C.J., Blennerhassett J.B.: Spontaneous acroangiodermatitis in a young woman. Dermatol Online J 2004, 10, 8.

5. Kanitakis J., Narvaez D., Claudy A.: Expression of the CD34 antigen distinguishes Kaposi's sarcoma from pseudo-Kaposi's sarcoma (acroangiodermatitis). Br J Dermatol 1996, 134, 44-46.

6. Pietkiewicz P., Bowszyc-Dmochowska M., Gornowicz-Porowska J., Majewski P., Marszałek A., Dmochowski M.: Acroangiodermatitis in a leg amputee using a suction-socket prosthesis: clinical, histological as well as HHV-8 and CD34 immunohistochemical study. Pol J Pathol 2013, 64, 153-156.

7. Ozkaya D.B., Su O., Onsun N., Ulusal H., Demirkesen C.: Non-healing ulcer on the foot: early onset unilateral Mali-type acroangiodermatitis. Acta Dermatovenerol Alp Pannonica Adriat 2013, 22, 49-51.

8. Ghia D.H., Nayak C.S., Madke B.S., Gadkari R.P.: Stewart-bluefarb acroangiodermatitis in a case of Parkes-Weber syndrome. Indian J Dermatol 2014, 59, 406-408

9. Lugović L., Pusić J., Situm M., Buljan M., Bulat V., Sebetić K., et al.: Acroangiodermatitis (pseudo-Kaposi sarcoma): three case reports. Acta Dermatovenerol Croat 2007, 15, 152-157.

10. Coban I., Kokenek-Unal T.D., Alper M.: Spontaneous acroangiodermatitis. Indian J Dermatol 2015, 60, 268-271.

Received: 20.03 .2018

Accepted: 9.06.2018

Otrzymano: 20.03.2018 r.

Zaakceptowano: $9.06 .2018 \mathrm{r}$. 